\title{
A SYSTEMATIC USE OF ORAL HISTORIES TO PROMOTE HISTORICAL THINKING: HISTORICAL THINKING AND THE IRAQ WAR
}

\author{
Sarah Drake Brown \\ Ball State University
}

The use of oral history in the classroom is not new. Recent publications highlight successful oral history projects in elementary, middle, and high schools, and in colleges and universities. Recommendations for teachers at all levels interested in conducting oral history projects with students provide concrete directions and instructional support. ${ }^{1}$ These assignments undoubtedly contribute to students' development as historical thinkers and as citizens as they are asked to do historical research and consider their relationship to people in the past as part of the larger human experience. Historians express confidence with respect to the value of having students do oral history.

While engaging students in conducting oral history interviews is certainly a worthwhile endeavor, historians might also consider ways to incorporate into their history teaching the voluminous oral histories that already exist. Oral histories pertaining specifically to veterans' experiences are growing in number. Each branch of the United States' armed services has designated agencies responsible for collecting and maintaining primary sources pertaining to veterans, and the Internet has made these sources easily accessible for teachers. ${ }^{2}$ This essay emphasizes the use of existing oral history interviews that focus on the recent past-veterans' experiences in the war in Iraq - and describes a systematic approach to source analysis designed to promote historical thinking among undergraduates as they consider leadership and the cost of victory in Iraq.

\section{Systematic Source Organization}

Primary sources appear frequently in history classrooms. Primary sources can reveal to students what the professor already knows or provide examples and evidence to students to demonstrate points made during a lecture. The method of source analysis

\footnotetext{
${ }^{1}$ For recent examples, see Michael Lynch, "Every Soldier Has a Story: Creating a Veterans Oral History Project," OAH Magazine of History, 22:4 (October 2008), 37-40; Paul Aleckson, "The D.C. Everest Oral History Project," Perspectives on History, 40:3 (March 2011), 25-27; Patrick Hagopian, "Voices from Vietnam: Veterans' Oral Histories in the Classroom," The Journal of American History, 87:2 (September 2000), 593-601; Daniel A. Kelin, To Feel as Our Ancestors Did: Collecting and Performing Oral Histories (Portsmouth, NH: Heinemann, 2005); Donald A. Ritchie, Doing Oral History: A Practical Guide, $2^{\text {nd }}$ ed. (New York: Oxford University Press, 2003).
}

${ }^{2}$ Lynch, "Every Soldier Has a Story," 39-40. 
that follows seeks to make students active participants in the historical process. This systematic method models for students the crafting of a thesis and the examination of sources to support or challenge that thesis. The method emphasizes deliberative discussion and historical thinking as the teacher and students consider the relationship among sources and the ways in which sources can "talk" to each other. ${ }^{3}$

In the following approach to source analysis, one document serves as a central text against which other sources are compared. The main document should represent the heart of a historical issue or period, and it should articulate a position clearly. This document is surrounded by other sources that support or challenge the position articulated clearly by the original document. It is crucial that at least one of these sources challenge the position outlined in the first source introduced to students.

As the teacher and students examine and discuss the sources assembled together, they must address a central question. This question should be open-ended and invite deliberation and interpretation of the sources. The design of the question emerges for the historian during the planning stage as he or she establishes the intellectual direction of the class sessions incorporating this model. The selection of the main document is, by its very nature, an interpretative act. By identifying a key document and assembling various other sources, the teacher is articulating a thesis and offering an interpretation of the past. The central question must compel undergraduates to consider the content promulgated in the sources and the ways of thinking made possible by the act of interpretation. As the teacher and students work together to study, question, and interpret the sources, students then take responsibility for investigating further and identifying an additional source.

The additional source is a source selected by students that either supports or challenges the position articulated in the first document. The inclusion of the additional source is critical. Selecting this source compels students to utilize skills in historical research and measures their ability to relate sources and the ideas in sources to one another. By bringing their own source to the table and engaging in deliberations that are historical in nature, students become equal participants in the process of historical study. By weighing evidence and examining the extent to which their source supports or challenges the source used by their professor, students learn valuable skills pertaining to historical comprehension, analysis and interpretation, and issues-analysis and decision-making. As they defend their selections and relate their source to the original document, they are compelled to recognize the position of others and acknowledge the interpretive nature of the past. I believe that it is especially crucial to require students to turn to sources to support their positions when we ask them to

${ }^{3}$ For a complete description of the method, see Frederick D. Drake and Sarah Drake Brown, "A Systematic Approach to Improve Students' Historical Thinking," The History Teacher, 36:4 (August 2003), 465-489; Frederick D. Drake and Lynn R. Nelson, Engagement in Teaching History: Theory and Practices for Middle and Secondary Teachers, $2^{\text {nd }}$ ed. (Upper Saddle River, NJ: Pearson, 2009), 138155. 
discuss issues that pertain to the recent past. The description that follows provides an example of how historians might use this systematic method of source analysis with undergraduates in order to investigate the war in Iraq and the perspectives of soldiers in the war as recorded through oral history interviews.

The First Division Museum at Cantigny in Wheaton, Illinois, preserves the history of the U.S. Army's First Infantry Division, commonly known as the "Big Red One." In the summer of 2008, students at Ball State University in Muncie, Indiana, interviewed forty veterans from the Big Red One in an effort to preserve the memories of soldiers who have served as part of this distinguished unit since the 1940s. In 2009, the second phase of this process began and included 22 interviews of veterans and active duty personnel serving from 1944 to 2009. Students at Ohio University conducted the Phase II interviews. ${ }^{4}$ Several of the Phase II interviews focused on American soldiers' experiences in Iraq, and the primary sources in the example outlined on the following pages draw from the context of the Iraq War and the experiences described by these soldiers. ${ }^{5}$

\section{Leadership and the Cost of War}

When using multiple sources with undergraduates, I seek to ensure that the sources are organized under a specific and identifiable theme. While the work of the National Council for History Education (NCHE) focuses mainly on the pre-collegiate teaching of history, its offerings lend well to the organization of undergraduate courses. For example, NCHE has identified six vital themes and narratives for the teaching of history. The theme of values, beliefs, political ideas, and institutions often provides me with structure for specific historical content. When investigating the United States' involvement in Iraq, the theme proves especially pertinent. It emphasizes "The interplay among ideas, material conditions, moral values, and leadership, especially in the evolution of democratic societies [and] the tensions between the aspirations for freedom and security, for liberty and equality, and for distinction and commonality in

${ }^{4}$ Professors Michael Doyle and David Ulbrich directed the project in both phases and participated in teaching students the methods of conducting oral history interviews. The McCormick Foundation and Cantigny First Division Foundation provided financial support for both phases of the project and for the development of teaching materials.

\footnotetext{
${ }^{5}$ As part of the Phase II project, history education majors at Ball State designed research kits that incorporated the oral histories from the Cantigny Project. The four research kits designed by content methods students for this project can be viewed at http://media.library.ohiou.edu/cantigny/lessons/html. The sources utilized in these kits provide the basis for this essay.
} 
human affairs." I I also seek to identify specific aspects of historical thinking to guide my students' work. NCHE offers history's habits of mind for this purpose. When examining sources pertaining to U.S. actions in Iraq, I want students to consider "how things happen and how things change, how human intentions matter, but also how their consequences are shaped by the means of carrying them out, in a tangle of purpose and process." I have found that pointing out to students both the theme and habit of mind that will guide our examination of sources helps them better understand our purposes in class and assists them in focusing on both acquiring content knowledge and considering how they are thinking as together we pose questions about sources.

My central question when I join with students to examine the sources outlined below is "How do we understand both leadership and the cost of war?" The openended nature of the question is meant to invite consideration and foster discussion. In wording the question this way, I purposefully ask students to suspend judgment and avoid taking a position or an evaluative stance at the outset of source examination. The following sources serve as the basis for our analysis:

Main Document:

- President George W. Bush, "Mission Accomplished" Speech, May 1, 2003. ${ }^{8}$

Other sources:

- "Mission Accomplished," political cartoon, Frank Cammuso, Post-Standard, Syracuse, NY, May 4, 2003. ${ }^{9}$

- President George W. Bush, Ultimatum to Saddam Hussein, March 17, 2003. ${ }^{10}$

- Video of Charlie Rose Roundtable, March 17, 2003. ${ }^{11}$

${ }^{6}$ National Council for History Education, Building a History Curriculum: Guidelines for Teaching History in Schools (Washington, DC: Educational Excellence Network, 1988).

${ }^{7}$ Ibid.

${ }^{8}$ For the text and video file of President Bush's speech, see http://americanrhetoric.com/speeches/ wariniraq/gwbushiraq5103.htm.

${ }^{9}$ Stephen Hess and Sandy Northrop, American Political Cartoons: The Evolution of a National Identity, 1754-2010, first Transaction ed. (Piscataway, NJ: Transaction Publishers, 2011 ), 161.

${ }^{10}$ For a text of Bush's Ultimatum to Saddam Hussein, see http://news.bbc.co.uk/2/hi/americas/ 2859269.stm.

${ }^{11}$ The Charlie Rose segment can be located at http://www.charlierose.com/view/interview/2094. 
- Cantigny Oral History Interview with Colonel Roy Bourne. ${ }^{12}$

- Article Series from the Indianapolis Star, "A War Within," Aug. 30-Sept. 2, 2009. ${ }^{13}$

- Cantigny Oral History Interview with Captain Rashad Fulcher. ${ }^{14}$

When working with undergraduates, it is useful to consider research in history education pertaining to students' reading of historical sources. ${ }^{15}$ According to the leading scholar in the field, Sam Wineburg, historical thinking is an "unnatural act" but must be taught. Undergraduate students sometimes are familiar with the distinctions between primary and secondary sources, but they often mine texts for answers instead of engaging in disciplinary reading skills. Therefore, it is imperative to instruct students to "source" a document. Prior to examining the main ideas, students must ask some specific questions: When was the document written, who wrote it, who was the intended audience, what was the articulated purpose, what was the context locally, nationally, or internationally for the creation of the document, and so forth? It is then important to push students to consider other questions that are specific to the particular document under study. In this case study of the Iraq war, the following questions might be appropriate:

- What mission had the United States articulated in early 2003? To what extent had the U.S. accomplished the mission?

\footnotetext{
${ }^{12}$ For the interview with Roy Bourne, see http://cdm15808.contentdm.oclc.org/cdm $/ \mathrm{search} / \mathrm{collection} /$ cantigny/searchterm/roy\%20bourne/order/title.

${ }^{13}$ The series in the Indianapolis Star is located at http://www.indystar.com/article/20090830/NEWS/ 908300316/Day-1-lost-two-good-friends-m-having-hard-time-dealing.
}

\footnotetext{
${ }^{14}$ For Rashad Fulcher's interview, see http://cdm15808.contentdm.oclc.org/cdm/search/collection/ cantigny/searchterm/rashad $\% 20$ fulcher/order/title
}

\footnotetext{
${ }^{15}$ Research in history education pertains both to pre-collegiate and collegiate thinking. For example, see Sam Wineburg, Historical Thinking and Other Unnatural Acts: Charting the Future of Teaching the Past (Philadelphia: Temple University Press, 2001); Peter Stearns, Peter Seixas, and Sam Wineburg, eds., Knowing, Teaching, and Learning History (New York: New York University Press, 2000); Mario Carretero and James F. Voss, eds., Cognitive and Instructional Processes in History and the Social Sciences (Hillsdale, NJ: Lawrence Erlbaum Associates, Inc., 1994); David Pace and Joan Middendorf, eds., Decoding the Disciplines: Helping Students Learn Disciplinary Ways of Thinking (Hoboken, NJ: Wiley Periodicals, 2004); David Pace, "The Amateur in the Operating Room: History and Scholarship of Teaching and Learning," American Historical Review, 109 (October 2004), 1171-1 192; David Pace and Keith Erekson, "The Scholarship of Teaching and Learning History Comes of Age: A New International Organization and Web Site/Newsletter," The History Teacher, 40 (November 2006), 75-78; also see Indiana University's History Learning Project, http://www.iub.edu/ hlp/index.html (accessed January 4, 2012).
} 
- To what extent had the mission changed?

- What effect might the words "mission accomplished" have on an audience?

- How did President Bush define major combat operations?

- What was Bush's purpose when delivering the speech?

- Why might Bush have referenced FDR, Truman, and Reagan?

- What clues might the speech provide about Bush's perception of leadership? His perception of victory in war?

- In what ways does Bush address the cost of war?

Rather than asking students for their reaction today to President Bush's speech, it is crucial to remind students to consider the reaction of television viewers in 2003. (While undergraduates might recall the speech, most of them were between 9 and 13 years old when Bush delivered the address. ${ }^{16}$ After we arrive at a consensus about the meaning of the speech at the time it was delivered and the reactions of the American public (perhaps accomplished in one or two class sessions), it is time to move to a closer examination of sources that both support and challenge the central idea articulated in the main document. The other sources listed above then can be used to engage students in an examination of and ongoing dialogue about U.S. actions in Iraq.

After working with students to analyze a text, I often next turn to an image or a political cartoon. In this case, Frank Cammuso's May 4, 2003, political cartoon in the Syracuse Post-Standard provides a way to begin an examination of some of the public reaction to Bush's speech. For students who struggle with source analysis, it also provides a quick reminder of some of the key points of the "Mission Accomplished" address.

I use President Bush's March 17, 2003, Ultimatum to Saddam Hussein and a subsequent roundtable from the "Charlie Rose" program on PBS as the next sources we examine. Bush's ultimatum follows our reading of the "Mission Accomplished" speech because, when speaking on March 17, Bush outlined the United States' mission in Iraq. The speech specifies why Bush is giving Saddam Hussein and his sons 48 hours to leave the country. In this speech, the President also charges permanent members of the Security Council in the United Nations as lacking resolve in regard to Iraq. This marked shift in U.S. foreign policy and the formation of what would become known as the Bush Doctrine sets the stage for an examination of the role of a leader and how the American public responds to different approaches to leadership. The roundtable on "Charlie Rose" includes perspectives of journalists associated with the Washington Post, New York Times, and International Herald Tribune. When using television programs, I find it useful to select specific segments from the program and to encourage

\footnotetext{
${ }^{16}$ Since the speech was broadcast on television, it seems appropriate to have students watch the speech and perhaps have a textual copy in hand. I have wondered the extent to which student reactions to the speech might differ if they only read it rather than view it in its entirely.
} 
students to view the remainder of the episode independently. While I select segments I deem essential (in this case, the beginning portion of the program), I find it useful to be familiar enough with the entire show to be able to skip to specific exchanges based on students' reaction to and analysis of the source.

The oral history interview with Colonel Roy Bourne serves as our next point of examination. The interview (specifically minutes 49:00-1:03:16 in the video transcript) incorporates the ideas of both leadership and the cost of war. Bourne's definition of leadership emphasizes the idea that good leaders recognize that set answers do not often work and that leadership depends on the ability to use the right skill set based on the position one is in. The Colonel also addresses the difficulty of being in a position of leadership when soldiers are lost in combat. In the last portion of the interview, Bourne explains that leaders are often plagued by the question, "Did we do everything?" when lives are lost. He also comments on the difficulty of reflecting and then moving on in decision-making after soldiers die, but he emphasizes the necessity of doing so. The final minutes of the interview include Boume's perspective on soldiers' return to civilian life. He comments on improvements that have been made and that still need to be made when veterans return from active duty, and he explains what he considers to be a common perspective among veterans: The idea that if it didn't happen in Iraq, nothing bad can happen at home. The interview with Colonel Roy Boume provides a crucial connection between the other sources used in this analysis. Bourne's comments on leadership and the cost of war for individual soldiers link the "political" sources that examine policies of the Bush administration with the experiences of American soldiers as described in the Indianapolis Star's series, "A War Within."

Between August 30 and September 2, 2009, the Indianapolis Star ran a four-day feature focusing on a tragedy surrounding the $1451^{\text {st }}$ Transportation Company. Two members of the Company, Sgt. Joshua Schmit and Sgt. Brandon Wallace, were killed when a roadside bomb destroyed a Humvee during their final mission in Iraq on April 14,2007 . Four members of the $1451^{\text {st }}$ took their own lives upon returning to civilian life. Interviews with more than fifty current and former members of the $1451^{\text {st }}$ Transportation Company and interviews with representatives from the Department of Veterans Affairs and the U.S. Army were conducted for this series of articles that provides students with an opportunity to consider the costs of war that occur beyond the battlefield.

The final source is the oral history interview with Captain Rashad Fulcher (17:43-20:00 in the interview). Fulcher is responsible for carrying out "sacred duties," meaning he must notify immediate family members of the death or injury of loved ones as a result of combat. Fulcher emphasizes the extent to which such notifications "bring home" the cost of freedom.

During the examination of all sources, we constantly return to the central question, "How do we understand both leadership and the cost of war?" As students use the sources to support or challenge the position articulated in Bush's "Mission 
Accomplished" speech, they should begin to consider what sources they will bring to class and relate to the main source. My approach to additional student sources (those sources students bring to class to address the central question in support of or challenge to the position articulated by the main source) varies depending on the group of students with which I am working. Sometimes it is not necessary for me to provide many suggestions in regard to potential sources students might explore, and other times it is important for me to provide specific lists of sources they might consider. Depending again upon the particular group of students, it might be appropriate to pose further questions for consideration in addition to those we have examined together. For example, in this case, a question such as "What are the potential benefits of war?" might be useful. Sources addressing the goals of eliminating a tyrant, fostering democracy, and attempting to stabilize a region would contribute to the overall deliberation about our understandings of leadership and the cost of war.

\section{Conclusion}

Despite the contemporary nature of the content in the sources assembled for discussion, it is not my intent to utilize a controversial political issues (CPI) format. ${ }^{17}$ Rather, I seek to draw upon the discipline of history and to use contemporary sources to promote specific habits of mind and disciplinary thinking processes. Instead of asking undergraduates to judge whether or not the United States should have been in Iraq or to evaluate whether or not the United States' actions were justified (questions that would have been more along the line of a CPI discussion), it was my intent to pose a question that would invite deliberative discussion without asking students to choose sides at the outset.

Historians often must grapple with the challenge of examining contemporary events and the establishment of policies without the benefit of the historiographic lens. Perhaps by utilizing the ways of thinking promoted by the discipline of history, merging these processes with a systematic analysis of sources that consists of collective memories and perceptions of the recent past in the public mind and in the minds of individuals who have spoken of their lived experiences, and drawing upon deliberative methods of discussion, both teachers and students of history can engage in responsible discourse that promotes the measured thought vital to democratic life and a civil society.

\footnotetext{
${ }^{17}$ Diana E. Hess has conducted extensive research on teachers' use of discussion around controversial political issues. Her valuable work contributes to promoting democratic discussions in social science classrooms. While the approach advocated by the systematic method outlined in this essay is not in conflict with Hess's ideas, it relies more on the disciplinary structure of history in source analysis than does a CPI discussion. For more on CPI, see Diana E. Hess, Controversy in the Classroom: The Democratic Power of Discussion (New York: Routledge, 2009).
} 